\title{
Electrochemical pretreatment of distillery wastewater using aluminum electrode
}

\author{
B. M. Krishna $\cdot$ Usha N. Murthy • \\ B. Manoj Kumar $\cdot$ K. S. Lokesh
}

Received: 17 June 2009/Accepted: 23 November 2009/Published online: 11 December 2009

(C) Springer Science+Business Media B.V. 2009

\begin{abstract}
Electrochemical (EC) oxidation of distillery wastewater with low $\left(\mathrm{BOD}_{5} / \mathrm{COD}\right)$ ratio was investigated using aluminum plates as electrodes. The effects of operating parameters such as $\mathrm{pH}$, electrolysis duration, and current density on COD removal were studied. At a current density of $0.03 \mathrm{~A} \mathrm{~cm}^{-2}$ and at $\mathrm{pH} 3$, the COD removal was found to be $72.3 \%$. The $\mathrm{BOD}_{5} / \mathrm{COD}$ ratio increased from 0.15 to 0.68 for an optimum of 120-min electrolysis duration indicating improvement of biodegradability of wastewater. The maximum anodic efficiency observed was $21.58 \mathrm{~kg}$ $\mathrm{COD} \mathrm{h}^{-1} \mathrm{~A}^{-1} \mathrm{~m}^{-2}$, and the minimum energy consumption observed was $0.084 \mathrm{kWh} \mathrm{kg}^{-1} \mathrm{COD}$. The kinetic study results revealed that reaction rate $(k)$ decreased from 0.011 to $0.0063 \mathrm{~min}^{-1}$ with increase in $\mathrm{pH}$ from 3 to 9 while the $k$ value increased from 0.0035 to $0.0102 \mathrm{~min}^{-1}$ with increase in current density from 0.01 to $0.03 \mathrm{~A} \mathrm{~cm}^{-2}$. This study showed that the COD reduction is more influenced by the current density. The linear and the nonlinear regression models reveal that the COD reduction is influenced by the applied current density.
\end{abstract}

\footnotetext{
B. M. Krishna $(\varangle) \cdot$ U. N. Murthy

Department of Civil Engineering, University Visvesvaraiah

College of Engineering, Bangalore University, Jnanabharathi

Campus, Bangalore 560 056, Karnataka, India

e-mail: bmkrishna_71@yahoo.com

U. N. Murthy

e-mail: ushanmurthy@yahoo.co.in

B. Manoj Kumar · K. S. Lokesh

Department of Environmental Engineering, Sri

Jayachamarajendra College of Engineering,

Mysore, 570 006, Karnataka, India

e-mail: manoj_kumar_b@hotmail.com

K. S. Lokesh

e-mail: lokeshkaggere@hotmail.com
}

Keywords Electrochemical oxidation . Distillery wastewater · Aluminum electrode

\section{Introduction}

Distillery is recognized as one of the most polluting industries, and waste in the form of "spent wash" is among the worst pollutants produced by distilleries both in magnitude and strength [1]. Most of the distilleries in India use cane molasses, a by-product of sugar industry as raw material. For every liter of alcohol produced, molasses-based distilleries generate $8-15 \mathrm{~L}$ of wastewater characterized by high Biochemical Oxygen Demand (BOD), high Chemical Oxygen Demand (COD), and high recalcitrant organics with dark color. Most of these organics are known to persist in nature [2]. This recalcitrance nature is due to the presence of melanoidin brown polymers that are having complex structure and toxicity toward biological agents, which are formed by Maillard amino-carbonyl reaction [3].

Various secondary treatment techniques have been tried for the removal of organic and recalcitrant pollutants and anaerobic digestion has gained wide acceptability due to methane recovery in the anaerobic step of the treatment. It has been found that anaerobic treatment results in $60-85 \%$ of the BOD reduction, but still substantial amount of recalcitrant organic pollutants are left behind which requires post treatment [4]. The most common postanaerobic treatment provided to distillery spent wash is aerobic treatment through activated sludge process or aerobic lagoons and similar processes. Though the anaerobicaerobic treatment for distillery wastewater result in notable COD reductions, they are not acceptable because of operational expenses and related economic reasons. In order to 
complicate the matters furthermore, refractory compounds such as polyphenols, which are toxic to microorganisms when present in high concentrations, greatly hinder the secondary aerobic biological treatment processes. Research study has also been carried out in the past to evaluate alternate options for abating the pollution potential of postdigested distillery effluent. They include physico-chemical treatment [5] and bioremediation using Pseudomonas species [6]. Studies have also been conducted on the evidence that the refractory organic compounds in anaerobically treated distillery effluent can be subjected for strong oxidants such as ozone and hydrogen peroxide [3].

Since $\mathrm{BOD}_{5} / \mathrm{COD}$ ratio of pretreated distillery wastewater is very low, further treatment by biological methods is very difficult; hence, there is a need to find out a technoeconomically feasible treatment method. Hence, many researchers have made attempts to use electrochemical methods for the treatment of high strength wastewater. The electrochemical treatment is an emerging technology used for the destruction of recalcitrant organics from different simulated wastewaters [7-9] as well as actual wastewaters [10-14]. The mechanism and application of electrochemical process for treatment of different industrial wastewater are reported by several authors [15-18].

The electrochemical treatment using chloride as the supporting electrolyte was reported for the treatment of different wastewaters such as lignin and tannic acid [19], resorcinol and cresols [20, 21], tannins [22], textile dye [23-26], landfill leachate [12], polyaromatic organic compounds [27], tannery [28, 29], pharmaceutical [30, 31], phenol and phenolic compounds [32-35], paper mill [36], and olive mill wastewaters [37].

Reports on the electrochemical treatment of anaerobically digested distillery effluents are very meager. Among them Manisankar et al. [3] have studied electrochemical treatment of industry treated effluent in a static electrochemical cell employing two different kinds of anodes viz., graphite and titanium anodes and stainless steel cathode under varying conditions of current density between 0.15 and $0.55 \mathrm{~A} \mathrm{~m}^{-2}$. Complete decolorisation and maximum COD and BOD removal of 92 and $98.1 \%$, respectively have been observed. Jegan et al. [38] have conducted experiment on distillery wastewater and observed $85-93.3 \%$ of COD removal for an electrolysis period of $6 \mathrm{~h}$ under varying flow rate using triple oxide-coated titanium as anode and stainless steel as cathode in a batch recirculation electrochemical cell.

From the above discussion, it is evident that, the treatability studies of the pretreated effluent in terms of enhancing $\mathrm{BOD}_{5} / \mathrm{COD}$ ratio and use of low cost electrodes have not been studied. Hence, it was found necessary to employ certain low cost anode materials in the electrochemical oxidation process to obtain maximum $\mathrm{BOD}_{5} /$ COD ratio and COD removal efficiency with optimized energy consumption. Hence, the main objective of this study is to investigate the applicability of electrochemical treatment for COD removal and to improve $\mathrm{BOD}_{5} / \mathrm{COD}$ ratio of distillery wastewater (wastewater collected from anaerobic lagoon of existing distillery wastewater treatment plant) using aluminum electrode. Furthermore, the effect of operating factors such as electrolysis duration, $\mathrm{pH}$, and current density on COD removal and improvement in $\left(\mathrm{BOD}_{5} / \mathrm{COD}\right)$ ratio were evaluated in this study.

\section{Materials and methods}

\subsection{Wastewater}

In this study, distillery wastewater was collected from the anaerobic lagoon of distillery wastewater treatment plant. It was subjected to treatability studies in the electrochemical batch reactor. The wastewater was analyzed for various parameters such as $\mathrm{pH}$, suspended solids, $\mathrm{COD}, \mathrm{BOD}$, and chlorides. The characteristics are shown in Table 1. It can be seen that the solids concentration is very high, and the COD and $\mathrm{BOD}_{5}$ values varied in the range of 42,240 46,440 and $6,757-8,600 \mathrm{mg} \mathrm{L}^{-1}$, respectively, which indicate that the wastewater contains high amount of organics. The initial $\left(\mathrm{BOD}_{5} / \mathrm{COD}\right)$ ratio was found to be very low in the range of $0.15-0.19$, which suggests that there is a presence of recalcitrant nature of organics in the wastewater.

\subsection{Electrochemical reactor setup}

Electrochemical oxidation experiments were conducted in a plexi-glass laboratory scale batch reactor of working

Table 1 Characteristics of distillery wastewater

\begin{tabular}{|c|c|}
\hline Parameters & $\operatorname{Range}^{\mathrm{a}}\left(\mathrm{mg} \mathrm{L}^{-1}\right)$ \\
\hline $\mathrm{pH}$ & $7.7-7.95$ \\
\hline Total solids & $36,500-37,800$ \\
\hline Total suspended solids & $11,140-11,400$ \\
\hline Total dissolved solids & $25,360-26,400$ \\
\hline $\mathrm{BOD}_{5}$ & $6,757-8,600$ \\
\hline COD & $42,240-46,440$ \\
\hline Chlorides & $6,300-7,200$ \\
\hline Phosphates & $320-367$ \\
\hline Sulfates & $85-120$ \\
\hline Nitrates & $200-225$ \\
\hline Conductivity $\left(\mathrm{ms} \mathrm{cm}^{-1}\right)$ & $400-560$ \\
\hline $\mathrm{BOD}_{5} / \mathrm{COD}$ ratio & $0.15-0.19$ \\
\hline
\end{tabular}

${ }^{\text {a }}$ Values observed for wastewater collected from anaerobic lagoon of existing distillery wastewater treatment plant 
volume $1.5 \mathrm{~L}$ with dimensions $13.5 \mathrm{~cm} \times 19 \mathrm{~cm} \times$ $14.5 \mathrm{~cm}$. The aluminum plate of size $5 \mathrm{~cm} \times 5 \mathrm{~cm}$ was used as both anode and cathode electrode. The electrodes were placed at a fixed distance of $2 \mathrm{~cm}$ apart by the head plate of the reactor. The experimental setup is shown in Fig. 1. A direct current power supply unit (Textronix-35D, 0-10 A, 1-15 V) was used for current supply. The reactor was operated under completely mixed condition facilitated by a magnetic stirrer to avoid concentration gradients. The samples were collected at regular time interval from the sampling port provided in the reactor, and the samples were analyzed for various parameters. All the analytical procedures followed the standard methods for examination of water and wastewater [39]. The experiments were conducted to study the effect of the three operating conditions viz., electrolysis duration (ED), $\mathrm{pH}$, and current density (CD).

\subsection{Electrolysis experiments}

The batch studies were conducted at the existing $\mathrm{pH}$ of the post-methanation distillery wastewater to find the optimum electrolysis duration at which maximum COD removal takes place. At the optimum electrolysis duration, further experimental runs were conducted at $\mathrm{pH}$ of $3,5,7$, and 9 . The optimum $\mathrm{pH}$, which resulted in maximum COD removal, was fixed up for further experiments with varying current densities. Thus, all the experimental conditions such as duration of electrolysis, $\mathrm{pH}$, and current density were optimized on the basis of maximum percent COD removal efficiency.

\section{Mechanism of electrochemical oxidation}

Two important features of the electrochemical process are converting non-biocompatible organics into biocompatible compounds, and oxidation of organics into $\mathrm{CO}_{2}$ and $\mathrm{H}_{2} \mathrm{O}$. The degradation of organics and toxic materials present in the wastewater in an electrochemical process is achieved by direct or indirect oxidation. In the direct oxidation technique, pollutants are destroyed directly at the anode. The indirect oxidation process utilizes strong oxidizing agent such as chlorine/hypochlorite generated in situ during electrolysis for the oxidation of pollutants. Chlorides present in wastewater act as supporting electrolyte, and it generates strong oxidizing agents such as chlorine/hypochlorite during the process and used for the mineralization of organic pollutants. Both hypochlorite and free chlorine can react as oxidizing agents, and they lead to the following oxidation. The off-gases from the cell are collected and tested by passing the gas through lime water. It turned milky indicating the formation of $\mathrm{CO}_{2}$ during electrolysis [24, 40-42]. The reactions involved are

$\mathrm{C}_{a} \mathrm{H}_{b} \mathrm{~N}_{c} \mathrm{O}_{d}+[\mathrm{O}] \rightarrow a \mathrm{CO}_{2}+b / 2 \mathrm{H}_{2} \mathrm{O}+c / 2 \mathrm{~N}_{2}$

Organic matter $+\mathrm{OCl}^{-} \rightarrow \mathrm{CO}_{2}+\mathrm{H}_{2} \mathrm{O}+\mathrm{Cl}^{-}+$product.

The COD removal occurs only in the presence of chlorides in the bulk solution because of the reaction between the generated chlorine/hypochlorite and the organic molecules. The indirect electrochemical treatment involves the application of an electrical current to the wastewater containing chloride to convert chloride to chlorine/hypochlorite, and then
Fig. 1 Schematic diagram of electrochemical reactor setup

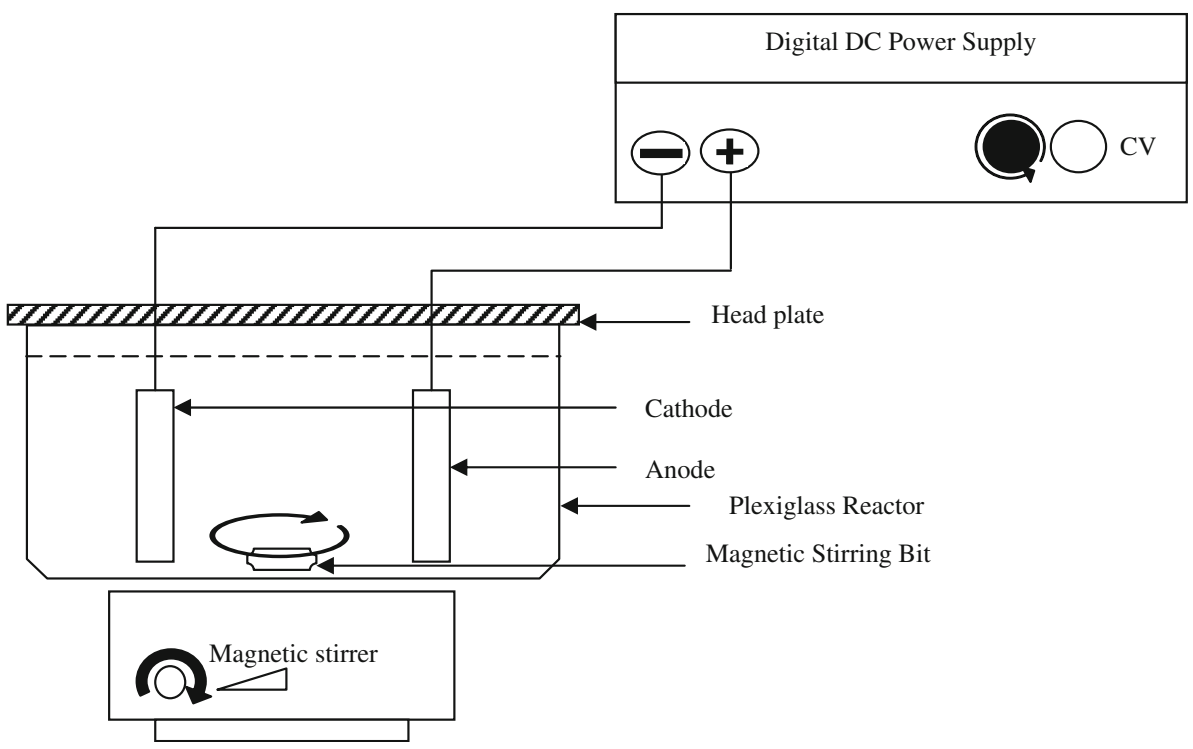


it oxidizes the pollutants. The hypochlorous acid and hypochlorite ion can decompose organic matter because of their high oxidative potentials [43].

At anode: $2 \mathrm{Cl}^{-} \rightarrow \mathrm{Cl}_{2}+2 \mathrm{e}^{-}$

At cathode: $2 \mathrm{H}_{2} \mathrm{O}+2 \mathrm{e}^{-} \rightarrow \mathrm{H}_{2}+2 \mathrm{OH}^{-}$

Bulk solution: $\mathrm{Cl}_{2}+\mathrm{H}_{2} \mathrm{O} \rightarrow \mathrm{HOCl}+\mathrm{H}^{+}+\mathrm{Cl}^{-}$

$\mathrm{HOCl} \rightarrow \mathrm{H}^{+}+\mathrm{OCl}^{-}$

In addition, electrocoagulation also occurs during electrochemical treatment of wastewater. Electrocoagulation is a complex and interdependent process. A sacrificial metal anode is used to produce coagulating agent to dose the polluted water, and electrolytic gases (mainly hydrogen at the cathode) are generated. Electrochemistry, coagulation, and hydrodynamics form the basis of electrocoagulation $[44,45]$. The most widely used electrode materials in electrocoagulation process are aluminum and iron, sometimes steel. The electrical current causes the dissolution of metal into wastewater. The metal ions, at an appropriate $\mathrm{pH}$ value, can form wide ranges of coagulated species and metal hydroxides, or precipitate and adsorb dissolved contaminants [46]. In case of aluminum as electrode, the reactions are

At anode: $\mathrm{Al} \rightarrow \mathrm{Al}^{3+}+3 \mathrm{e}^{-}$

At cathode: $3 \mathrm{H}_{2} \mathrm{O}+3 \mathrm{e} \rightarrow 3 / 2 \mathrm{H}_{2}+3 \mathrm{OH}^{-}$.

$\mathrm{Al}^{3+}$ and $\mathrm{OH}^{-}$ions generated by electrode reactions (7) and (8) react to form various monomeric species such as $\mathrm{Al}(\mathrm{OH})^{2+}, \mathrm{Al}(\mathrm{OH})_{2}^{+}, \mathrm{Al}_{2}(\mathrm{OH})_{2}^{4+}, \mathrm{Al}(\mathrm{OH})_{4}^{-}$, and polymeric species such as $\mathrm{Al}_{6}(\mathrm{OH})_{15}^{3+}, \mathrm{Al}_{7}(\mathrm{OH})_{17}^{4+}, \mathrm{Al}_{8}(\mathrm{OH})_{20}^{4+}, \mathrm{Al}_{13} \mathrm{O}_{4}$ $(\mathrm{OH})_{24}^{7+}, \mathrm{Al}_{13}(\mathrm{OH})_{34}^{5+}$, which transform finally into $\mathrm{Al}(\mathrm{OH})_{3}$. During electrocoagulation process, metal hydroxides formation occurs, and the flocs have a larger surface area, which is beneficial for a rapid adsorption of soluble organic compounds and trapping of colloidal particles. Finally, these flocs are removed easily from aqueous medium by sedimentation or flotation [47-49].

\section{Results and discussion}

\subsection{Effect of electrolysis duration}

The initial sets of experiments were conducted at the existing wastewater $\mathrm{pH}$ of 7.95 without any $\mathrm{pH}$ adjustment and at a current density of $0.03 \mathrm{~A} \mathrm{~cm}^{-2}$ (amounting to total current of $0.75 \mathrm{~A}$ ). It is evident from Fig. 2, that maximum of $48.76 \%$ COD reduction has been achieved in $120 \mathrm{~min}$ of electrolysis duration. The experiment was continued for $3 \mathrm{~h}$, and there was slight decline in COD removal. This may be due to the exhaustion of hypochlorite $\left(\mathrm{HClO}_{3}{ }^{-}\right)$ and free chlorine generation in situ in the reactor (indirect

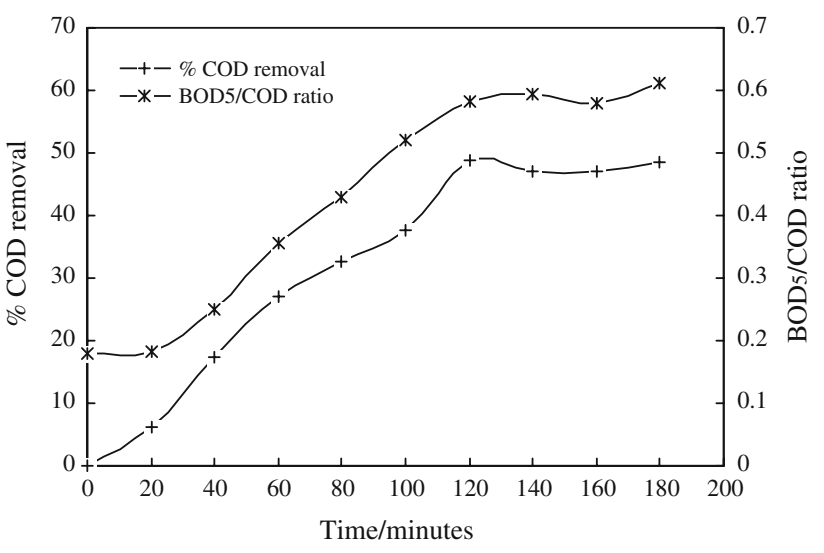

Fig. 2 Variation of COD removal efficiency and $\mathrm{BOD}_{5} / \mathrm{COD}$ ratio as a function of electrolysis duration

oxidation), and second, due to deposition of toxic metals/ materials on the anode (direct oxidation) which might have further prevented COD removal. It can be observed that $\mathrm{BOD}_{5} / \mathrm{COD}$ ratio increased from 0.17 to 0.58 at $120 \mathrm{~min}$, suggesting increase in biodegradability with an increase in electrolysis duration. In this experiment, the COD reduced from initial concentration of 42,240 to $21,640 \mathrm{mg} \mathrm{L}^{-1}$ while the BOD increased from the initial value of 7,520 to $12,616 \mathrm{mg} \mathrm{L}^{-1}$ at optimum electrolysis duration of 120 min. The increase in BOD concentration is attributed to the fact that some of the organics have broken down into smaller fragments, which are more biodegradable than parent compounds [31].

\subsection{Effect of $\mathrm{pH}$}

In order to know the effect of wastewater $\mathrm{pH}$ on performance of electrolysis, individual experiments were conducted at varying wastewater $\mathrm{pH}$ of $3,5,7$, and 9 with a constant current density of $0.03 \mathrm{~A} \mathrm{~cm}^{-2}(0.75 \mathrm{~A})$. Based on the previous experiment the electrolysis duration was fixed at $120 \mathrm{~min}$. The $\mathrm{pH}$ of wastewater was adjusted using $\mathrm{NaOH}$ or $\mathrm{H}_{2} \mathrm{SO}_{4}$ to get the desired $\mathrm{pH}$ throughout each run. As seen from Fig. 3, there was considerable effect on COD removal with varying wastewater $\mathrm{pH}$. The maximum COD reduction of $70.51 \%$ was observed at wastewater $\mathrm{pH} 3$, and the minimum COD reduction of $50.2 \%$ was observed at wastewater $\mathrm{pH} 9$. At wastewater $\mathrm{pH}$ of 7 and 5, the COD removal rates were 53.42 and $66.71 \%$, respectively. This shows that acidic condition is more favorable for the treatment of distillery wastewater. During this experiment at wastewater $\mathrm{pH}$ of 3 , the COD reduced from 44,700 to $13,180 \mathrm{mg} \mathrm{L}^{-1}$ while BOD increased from 8,600 to $9,015 \mathrm{mg} \mathrm{L}^{-1}$. The $\mathrm{BOD}_{5} / \mathrm{COD}$ ratio exhibited an analogous optimum increase from 0.19 to 0.68 at $\mathrm{pH} 3$ as shown in Fig. 4. It is observed that the COD removal rate and $\mathrm{BOD}_{5} / \mathrm{COD}$ ratio decreases with increase in $\mathrm{pH}$ of the 


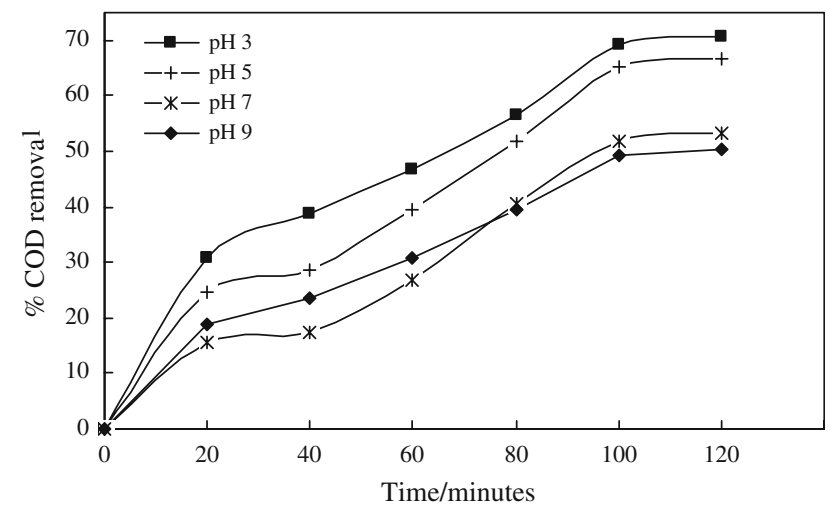

Fig. 3 Effect of pH on COD removal

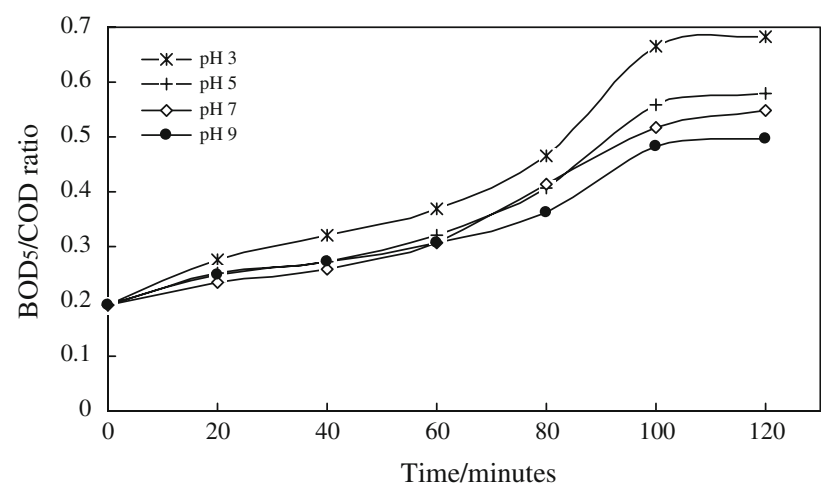

Fig. 4 Effect of $\mathrm{pH}$ on $\mathrm{BOD}_{5} / \mathrm{COD}$ ratio

solution. The reason may be due to the decreased production of chlorine/hypochlorite at higher $\mathrm{pH}$ condition, because of the formation of chlorate and perchlorate, which is according to the following equations.

$6 \mathrm{HOCl}+3 \mathrm{H}_{2} \mathrm{O} \rightarrow 2 \mathrm{ClO}_{3}^{-}+4 \mathrm{Cl}^{-}+12 \mathrm{H}^{+}+3 / 2 \mathrm{O}_{2}+6 \mathrm{e}^{-}$

$\mathrm{ClO}_{3}^{-}+\mathrm{H}_{2} \mathrm{O} \rightarrow \mathrm{ClO}^{-}+2 \mathrm{H}^{+}+2 \mathrm{e}$.

Another reason may be that at acidic $\mathrm{pH}$ condition, the chlorine is present in the solution in the form of hypochlorous acid, which is having higher oxidation potential $\left(E^{0}=1.49 \mathrm{~V}\right)$ than that of hypochlorite ion $\left(E^{0}=0.94 \mathrm{~V}\right)$ and the hypochlorite prevalent in alkaline $\mathrm{pH}$ condition $[43,50,51]$.

\subsection{Effect of current density}

An important operational variable of the electrochemical degradation process is the current density, which is the current input divided by the surface area of the electrode. In order to study the effect of varying current density on $\mathrm{COD}$ reduction and $\mathrm{BOD}_{5} / \mathrm{COD}$ ratio, experiments were done at different current densities of 0.01, 0.02, and

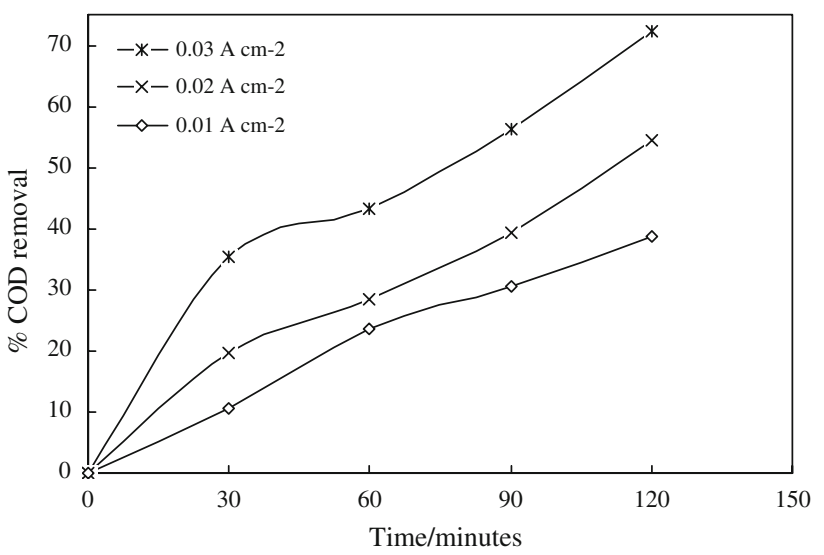

Fig. 5 Effect of current density on COD removal at wastewater $\mathrm{pH} 3$

$0.03 \mathrm{~A} \mathrm{~cm}^{-2}$ (amounting to a current of 0.25, 0.5, 0.75 A, respectively). The experiment was conducted for $120 \mathrm{~min}$ keeping constant electrode surface area and constant $\mathrm{pH}$ of 3. The experimental results of $\mathrm{COD}$ removal and $\mathrm{BOD}_{5} /$ COD ratio are shown in Figs. 5 and 6, respectively. From Fig. 5, it can be seen that the maximum COD removal of $72.3 \%$ was observed at an applied current density of $0.03 \mathrm{~A} \mathrm{~cm}^{-2}$. For initial $30 \mathrm{~min}$, the COD removal was rapid and later on it was gradual. While at current density of 0.01 and $0.02 \mathrm{~A} \mathrm{~cm}^{-2}$ the COD removal was gradual and at the end of electrolysis duration it was 38.7 and $54.5 \%$, respectively. The COD values reduced from initial concentration of $46,440-12,860 \mathrm{mg} \mathrm{L}^{-1}$ and the BOD increased from initial value of $6,757-8,820 \mathrm{mg} \mathrm{L}^{-1}$ at $0.03 \mathrm{~A} \mathrm{~cm}^{-2}$. Increasing current density led to the increase in COD reduction following Faraday's law [52], because of the increased production of chlorine/hypochlorite at higher current densities. The decrease of COD is attributed to the destruction of organic contaminants in wastewater, when the electro-oxidation was implemented. From Fig. 6 it is observed that there was an increase in $\mathrm{BOD}_{5} / \mathrm{COD}$ ratio from 0.15 to 0.68 at current density of $0.03 \mathrm{~A} \mathrm{~cm}^{-2}$ and further increase in current density had caused faster dissolution of anode material; hence, operating current density was not increased beyond $0.03 \mathrm{~A} \mathrm{~cm}^{-2}$, which is equivalent to a current of $0.75 \mathrm{~A}[31,53]$. The reason is that increasing current density, increases the overall potential required for the generation of chlorine/hypochlorite. At the same time, the performance of the reactor will be affected under different current densities while altering the other operating conditions simultaneously, as similar observation made by Rajkumar et al. [43]. In the treatment process the electro-oxidation of organic contaminants can occur directly on anodes by generating physically adsorbed active oxygen (adsorbed hydroxyl radicals, $\mathrm{OH}^{-}$) or the chemisorbed active oxygen (oxygen in the oxide lattice, $\left.\mathrm{MO}_{x+1}\right)$. The physically adsorbed active oxygen can cause the complete combustion of organic compounds (R), and 


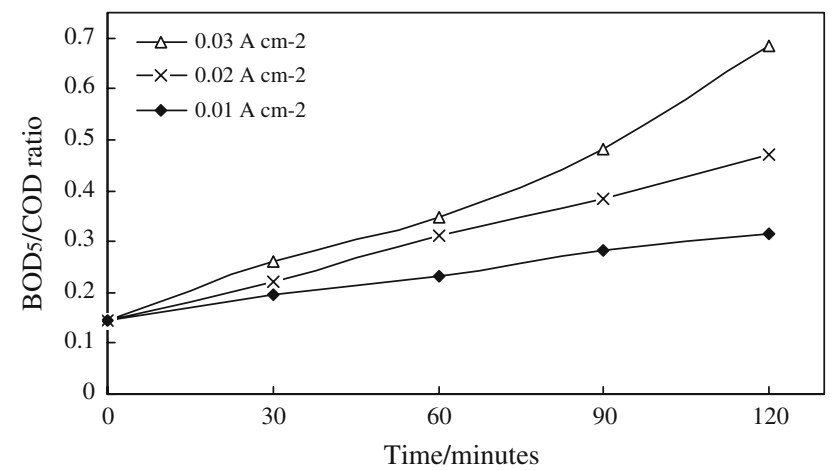

Fig. 6 Effect of current density on $\mathrm{BOD}_{5} / \mathrm{COD}$ ratio at wastewater $\mathrm{pH} 3$

the chemisorbed active oxygen can participate in the formation of selective oxidation products as shown in Eqs. 3 and 4. In general, $\mathrm{OH}^{-}$is more effective for pollutant oxidation than $\mathrm{O}$ in $\mathrm{MO}_{x+1}$ [42]. The performance of electrochemical reactor at an optimum $\mathrm{pH}$ of 3 and current density of $0.03 \mathrm{~A} \mathrm{~cm}^{-2}$ is shown in Table 2 .

$\mathrm{R}+\mathrm{MO}_{x}\left(\mathrm{OH}^{-}\right)_{z} \leftrightarrow \mathrm{CO}_{2}+z \mathrm{H}^{+}+z \mathrm{e}^{-}+\mathrm{MO}_{x}$

$\mathrm{R}+\mathrm{MO}_{x+1} \leftrightarrow \mathrm{RO}+\mathrm{MO}_{x}$.

\subsection{Anodic efficiency and energy consumption}

The anode efficiency of electrochemical treatment has been calculated in terms of $\mathrm{kg}$ COD removed per hour per ampere per square meter area of electrode $(\mathrm{kg} \mathrm{COD}$ $\mathrm{h}^{-1} \mathrm{~A}^{-1} \mathrm{~m}^{-2}$ ) and the energy consumption in terms of kilowatt hour per kilogram of COD removed $\left(\mathrm{kWh} \mathrm{kg}^{-1}\right.$

Table 2 Performance of electrochemical treatment (ECT)

\begin{tabular}{|c|c|c|}
\hline Parameters & $\begin{array}{l}\text { Before ECT } \\
\left(\mathrm{mg} \mathrm{L}^{-1}\right)\end{array}$ & $\begin{array}{l}\text { After ECT }{ }^{\mathrm{a}} \\
\left(\mathrm{mg} \mathrm{L}^{-1}\right)\end{array}$ \\
\hline $\mathrm{pH}$ & 7.8 & - \\
\hline Total solids & 36,800 & 20,200 \\
\hline Total suspended solids & 11,200 & 6,000 \\
\hline Total dissolved solids & 25,600 & 14,200 \\
\hline $\mathrm{BOD}_{5}$ & 6,757 & 8,820 \\
\hline COD & 46,440 & 12,860 \\
\hline Chlorides & 6,800 & 3,800 \\
\hline Phosphates & 340 & 52 \\
\hline Sulfates & 90 & 30 \\
\hline Nitrates & 210 & 40 \\
\hline $\begin{array}{l}\text { Conductivity } \\
\left(\mathrm{ms} \mathrm{cm}^{-1}\right)\end{array}$ & 510 & 430 \\
\hline $\mathrm{BOD}_{5} / \mathrm{COD}$ ratio & 0.15 & 0.68 \\
\hline
\end{tabular}

${ }^{a}$ Values observed at an optimum $\mathrm{pH} 3$ and at current density $0.03 \mathrm{~A} \mathrm{~cm}^{-2}$
COD removal) and the results are presented in Table 3 . This study was conducted at the wastewater $\mathrm{pH}$ of 3 and the current applied was $0.25,0.5$, and $0.75 \mathrm{~A}$. The maximum anodic efficiency of $21.58 \mathrm{~kg} \mathrm{COD} \mathrm{h}^{-1} \mathrm{~A}^{-1} \mathrm{~m}^{-2}$ and the minimum energy consumption of $0.084 \mathrm{kWh} \mathrm{kg}^{-1}$ COD removal was observed at $\mathrm{pH} 3$ and applied current of $0.25 \mathrm{~A}$. The anodic efficiency at $0.25 \mathrm{~A}$ is 1.6 times more than that at a current of $0.75 \mathrm{~A}$. Under similar conditions at $\mathrm{pH} 3$, the energy consumption increased 3.8 times with increase in current from 0.25 to $0.75 \mathrm{~A}$. This is in comparison with the studies made by Deshpande et al. [31] on electrochemical oxidation of pharmaceutical effluent. It is evident that increase in current density has actually resulted in decrease in anodic efficiency and increase in energy consumption.

\subsection{Kinetic studies}

In the electrochemical process, either direct or indirect oxidation process destroys the pollutants. It is generally observed that the direct oxidation of organic compounds at the surface is very difficult and the rate of reaction is too slow. Furthermore, pseudo first-order reaction kinetics was reported for most of the organic pollutants with chloride as supporting electrolyte. In indirect electrochemical oxidation process, the COD removal rate is proportional to the concentration of organic compound (pollutant) and also to the chlorine/hypochlorite concentration because the indirect oxidation is mediated by chlorine/hypochlorite. Therefore, the kinetics for COD removal is given as [54]:

$\mathrm{d}[\mathrm{COD}] / \mathrm{dt}=-\mathrm{K}[\mathrm{COD}] \mathrm{Cl}_{2}$.

Electrochemical treatment involves the application of an electrical current to the effluent to convert chloride to chlorine and hypochlorite. The chlorine and hypochlorite will oxidize the organic compound and then get reduced to a chloride ion. The process is then repeated in a catalytic fashion. Therefore, the concentration of chlorine/hypochlorite during the electrolysis is assumed to be constant and the above equation can be rewritten as a pseudo first-order equation [36].

$$
\begin{aligned}
& \mathrm{d}[\mathrm{COD}] / \mathrm{dt}=-\mathrm{K} \cdot[\mathrm{COD}] \\
& \mathrm{d}[\mathrm{COD}] /[\mathrm{COD}]
\end{aligned}
$$

Upon integrating from $t=0$ to $t=\mathrm{t}$ results in

$$
\ln \left[\mathrm{COD}_{t} / \mathrm{COD}_{0}\right]=-\mathrm{k} \cdot \mathrm{t}
$$

where $k=0.4343 \mathrm{~K}$.

The slope of the plot $\ln \left[\mathrm{COD}_{t} / \mathrm{COD}_{0}\right]$ versus time gives the value of reaction rate $(k)$ in $\min ^{-1}$. Here, the $\mathrm{COD}_{0}$ is the initial COD and $\mathrm{COD}_{t}$ is COD at time ' $t$ ' in $\mathrm{mg} \mathrm{L}^{-1}$.

The pseudo first-order plots of $\ln \left[\mathrm{COD}_{t} / \mathrm{COD}_{0}\right]$ versus time for different wastewater $\mathrm{pH}$ and different current 
Table 3 Anodic efficiency and energy consumption at varying current density

\begin{tabular}{llllll}
\hline $\mathrm{pH}$ & $\begin{array}{l}\text { Applied } \\
\text { current }(\mathrm{A})\end{array}$ & $\begin{array}{l}\text { Current density } \\
\left(\mathrm{A} \mathrm{cm} \mathrm{cm}^{-2}\right)\end{array}$ & $\begin{array}{l}\text { Voltage } \\
(\text { volts })\end{array}$ & $\begin{array}{l}\text { Anodic efficiency } \\
\left(\mathrm{kg} \mathrm{COD} \mathrm{h} \mathrm{A}^{-1} \mathrm{~m}^{-2}\right)\end{array}$ & $\begin{array}{l}\text { Energy consumption } \\
\left(\mathrm{kWh} \mathrm{kg} \mathrm{COD}^{-1}\right.\end{array}$ \\
\hline 3 & 0.25 & 0.01 & 4.54 & 21.58 & 0.084 \\
3 & 0.5 & 0.02 & 7.59 & 15.19 & 0.199 \\
3 & 0.75 & 0.03 & 10.76 & 13.43 & 0.320 \\
\hline
\end{tabular}

density for aluminum electrode are presented in Figs. 7 and 8 , respectively. Table 4 provides reaction rate $(k)$ and respective coefficient determination $\left(R^{2}\right)$ values for different $\mathrm{pH}$ and current density. From Fig. 7, it is observed that as the $\mathrm{pH}$ increases from 3 to 9 , the reaction rate $(k)$ decreases from 0.011 to $0.0063\left(\mathrm{~min}^{-1}\right)$ gradually. The maximum reaction rate $(k)$ was observed at acidic $\mathrm{pH}$ of 3 and minimum at $\mathrm{pH} 9$. As the pseudo first-order rate constant $(k)$ was calculated based on COD removal, the values of coefficient of determination $\left(R^{2}\right)$ are above 0.95 for different wastewater $\mathrm{pH}$ of 3-9. The reaction rate data reveal that distillery wastewater degrade easily at acidic $\mathrm{pH}$ than at higher $\mathrm{pH}$ values. Figure 8 shows the plots of $\ln$ $\left[\mathrm{COD}_{t} / \mathrm{COD}_{0}\right]$ versus time for different current densities $0.01,0.02$, and $0.03 \mathrm{~A} \mathrm{~cm}^{-2}$ (which is equivalent to applied current of $0.25,0.5$, and $0.75 \mathrm{~A}$, respectively). It is observed that the reaction rate $(k)$ increases from 0.0035 to $0.0102\left(\mathrm{~min}^{-1}\right)$ as the current density increases from 0.01 to $0.03 \mathrm{~A} \mathrm{~cm}^{-2}$. The maximum reaction rate was observed at current density of $0.03 \mathrm{~A} \mathrm{~cm}^{-2}$ and minimum at $0.01 \mathrm{~A} \mathrm{~cm}^{-2}$. The coefficients of determination $\left(R^{2}\right)$ values obtained are above 0.95. It shows that higher current density strongly influences on faster degradation of distillery waste. Chiang et al. [12] found that the chlorine/ hypochlorite production rate is improved by increasing current density during electrolysis. Therefore, enhancing effect of current density is attributed to the improvement of chlorine/hypochlorite production rate that enhances the indirect oxidation effect during electrolysis.

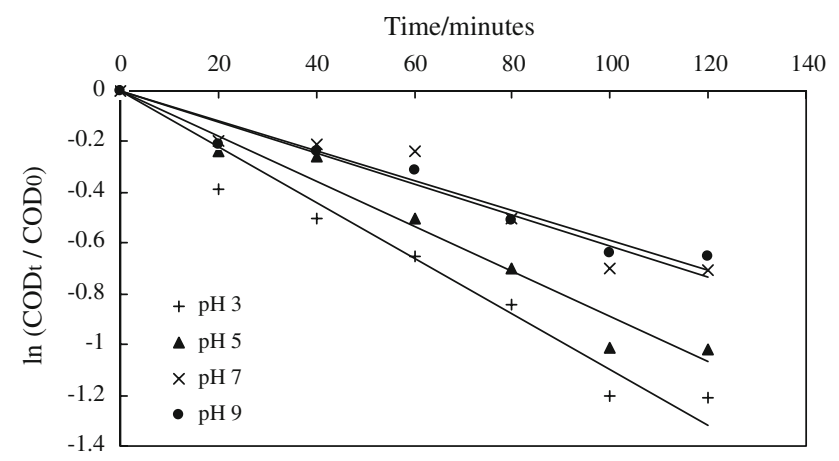

Fig. 7 Effect of $\mathrm{pH}$ on reaction rate

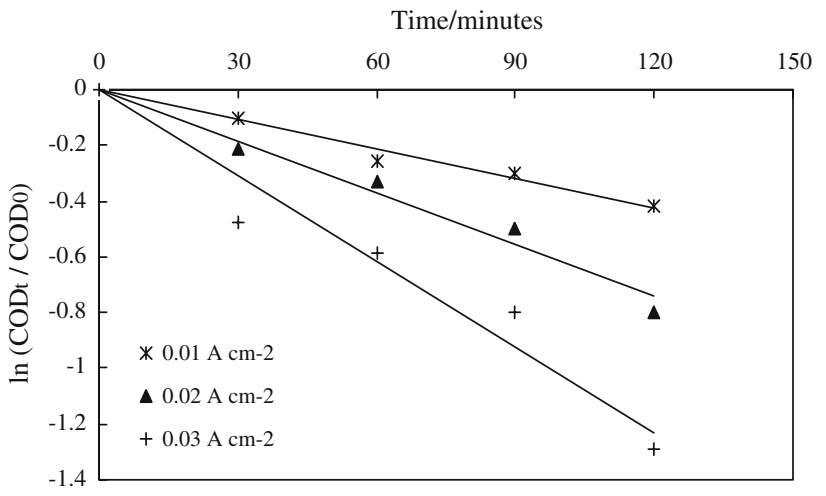

Fig. 8 Effect of current density on reaction rate

Table 4 Effect of $\mathrm{pH}$ and current density $(\mathrm{CD})$ on reaction rate $(k)$

\begin{tabular}{llllll}
\hline $\mathrm{pH}$ & $k$ & $R^{2}$ & $\mathrm{CD}\left(\mathrm{A} \mathrm{cm}^{-2}\right)$ & $k$ & $R^{2}$ \\
\hline 3 & 0.0110 & 0.9626 & 0.01 & 0.0032 & 0.9953 \\
5 & 0.0095 & 0.9723 & 0.02 & 0.0053 & 0.9787 \\
7 & 0.0065 & 0.9623 & 0.03 & 0.0102 & 0.9652 \\
9 & 0.0063 & 0.9660 & & & \\
\hline
\end{tabular}

\subsection{Instantaneous current efficiency}

The instantaneous current efficiency (ICE) was determined for the entire experimental batch studies carried out during the present work. The ICE is defined as the ratio of the current stoichiometrically required for the oxidation of organics to that of total consumption. This has been calculated in terms of COD variation as given in Eq. 16 $[24,27,33,55]$.

$$
\begin{aligned}
\operatorname{ICE}(\%)= & \left\{\frac{(\mathrm{COD})_{t}-(\mathrm{COD})_{t+\Delta t}}{8 \times I \times \Delta t}\right\} F \times V \times 100 \\
\operatorname{ICE}(\%)= & (\text { Decrease in COD }) \times(\text { volume of solution }) \\
& /(\text { mass of oxygen equivalent to electricity })
\end{aligned}
$$

where $\mathrm{COD}_{t}$ and $\mathrm{COD}_{(t+\Delta t)}$ are the COD values at times $t$ and $t+\Delta t$ (in grams of $\mathrm{O}_{2}$ per liter), respectively, $I$ is the current in amperes, $F$ is the Faraday's constant $26.8 \mathrm{Ah}$, and $V$ is the volume of electrolyte in liters [55]. Figures 9, 10 , and 11 show the variation of ICE for the three sets of 


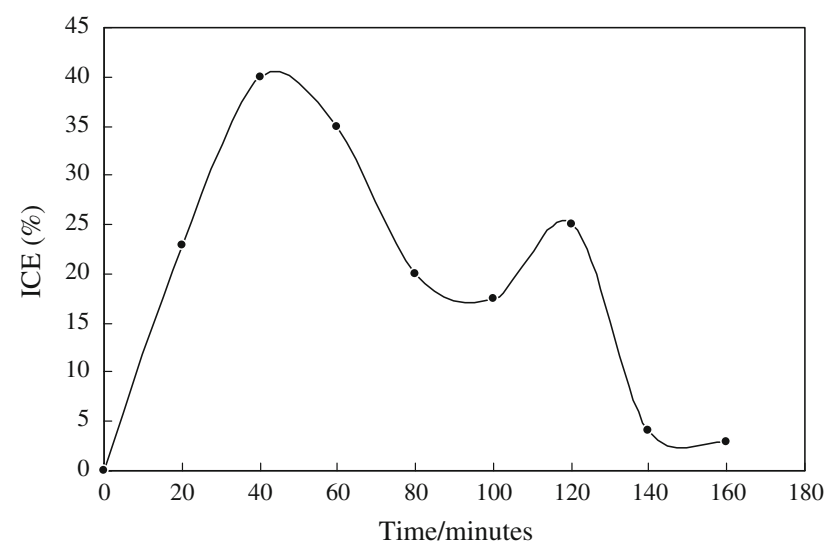

Fig. 9 Variation of instantaneous current efficiency (ICE) with respect to time as function of electrolysis duration

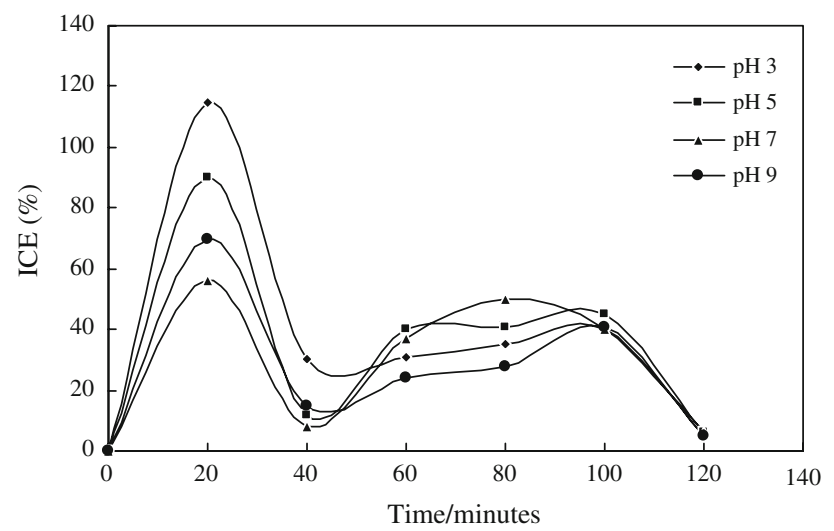

Fig. 10 Variation of ICE as a function of controlled $\mathrm{pH}$

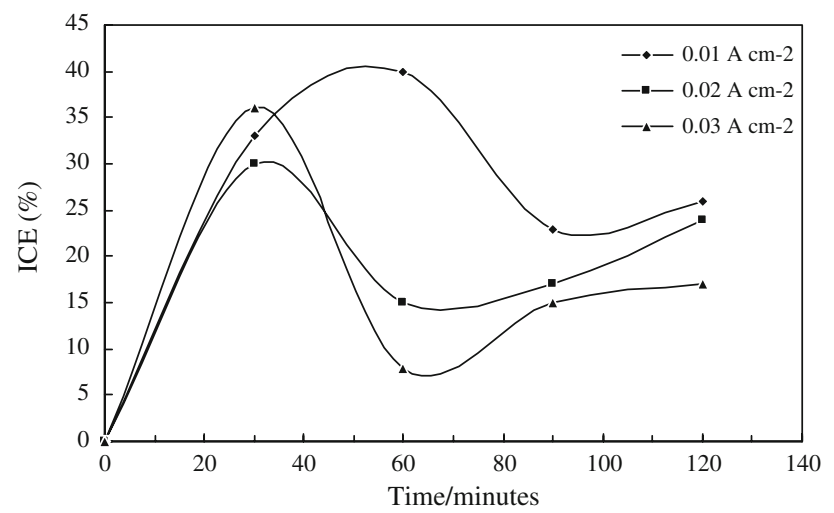

Fig. 11 Variation of ICE as a function of current density

experimental conditions viz., electrolysis duration, $\mathrm{pH}$, and current density. A common trend observed among all the plots is that, the ICE values have increased sharply during first $30 \mathrm{~min}$ and drop rapidly during further course of electrolysis. The probable cause for the decrease of ICE may be attributed to the growth of an adherent passivating film on the anode surface that might have poisoned the electrode or by production of stable intermediates that cannot be further oxidized by direct electrolysis [27]. Another possibility is that the decrease of ICE may be attributed to the adsorption of melanoidin, a polymeric material present in the distillery effluent, on the electrode surface or due to the formation of passivation film on the electrode surface by reaction between the metallic chloride and calcium or magnesium salts present in wastewater [3]. The ICE values in the first $30 \mathrm{~min}$ of treatment are higher than those in the last $90 \mathrm{~min}$ in all which indicates that the degradation during the first $30 \mathrm{~min}$ of treatment mainly contributes to the whole period.

\subsection{Regression analysis}

For the results obtained during the present study, multiple regression analysis was done using the software Regress version 3.0. Linear regression analysis was performed for $\mathrm{BOD}_{5} / \mathrm{COD}$ ratio and percent COD removal for electrochemically oxidized effluent. This analysis was intended to check the applicability of the experimental data in predicting the $\mathrm{BOD}_{5} / \mathrm{COD}$ ratio and percent $\mathrm{COD}$ removal also to identify the variables that contributes significantly to increase the $\left(\mathrm{BOD}_{5} / \mathrm{COD}\right)$ ratio and percent $\mathrm{COD}$ removal.

\subsubsection{Regression model-linear}

In each of the regression models the dependent variable is BOD/COD ratio $\left(Y_{1}\right)$ and percent COD removal $\left(Y_{2}\right)$ of electrochemically oxidized effluent, while the independent variables considered was duration of electrolysis $\left(X_{1}\right)$ in minutes, voltage applied $\left(X_{2}\right)$ in volts, and current density during electrolysis $\left(X_{3}\right)$ in $\mathrm{A} \mathrm{cm}^{-2}$. The data set consisted of 15 data points $(n=15)$. The models are mathematically expressed in Eqs. 17 and 18, as follows:

$Y_{1}=A_{0}+A_{1} X_{1}+A_{2} X_{2}+A_{3} X_{3}$

$Y_{2}=B_{0}+B_{1} X_{1}+B_{2} X_{2}+B_{3} X_{3}$

where $A_{0}$ and $B_{0}$ are constants and $A_{1}, A_{2}, A_{3}, B_{1}, B_{2}, B_{3}$ are the regression coefficients. The estimated linear model interrelating $\mathrm{BOD}_{5} / \mathrm{COD}$ ratio with the controlling parameters is presented in Eq. 19, which has correlation coefficient $\left(R^{2}\right)$ of 0.86 . From the model, the most significant controlling parameter of the system affecting $\mathrm{BOD}_{5} / \mathrm{COD}$ ratio is the current density $\left(X_{3}\right)$ and the least significant parameter is the electrolysis duration $\left(X_{1}\right)$.

$Y_{1}=0.02+0.002 X_{1}+0.011 X_{2}+4.945 X_{3}$.

The estimated linear model interrelating percent COD removal with the controlling parameters is given in Eq. 20, which has correlation coefficient $\left(R^{2}\right)$ of 0.93 . From the 


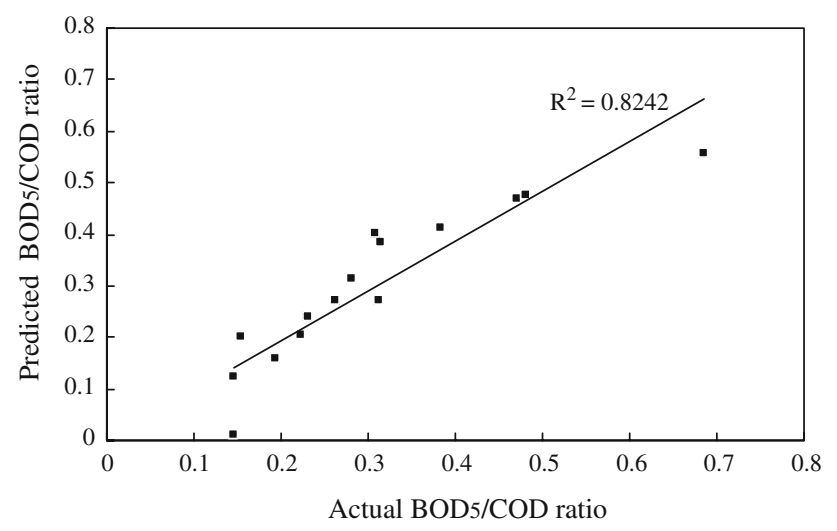

Fig. 12 Linear regression plot of actual and predicted values of $\mathrm{BOD}_{5} / \mathrm{COD}$ ratio

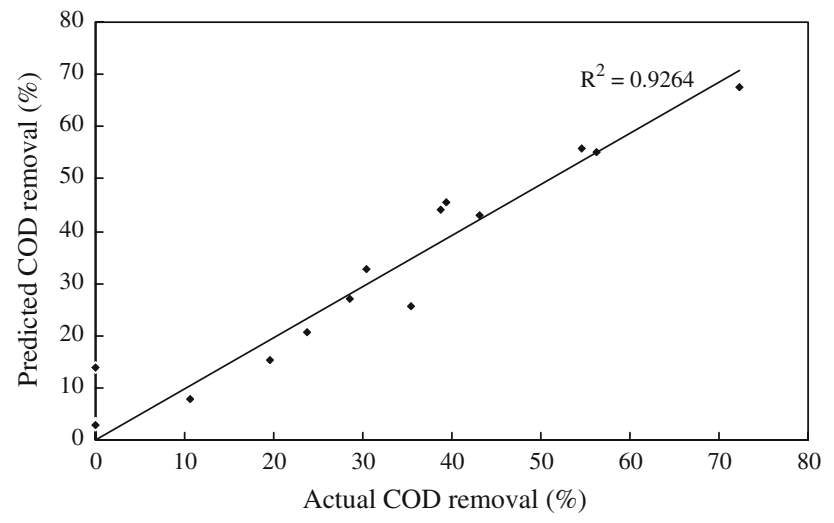

Fig. 13 Linear regression plot of actual and predicted values of percent COD removal

model, the most significant controlling parameter of the system affecting percent COD removal is the current density $\left(X_{3}\right)$ and the least significant parameter is the voltage applied $\left(X_{2}\right)$.

$Y_{2}=13.91+0.372 X_{1}+1.11 X_{2}+24.806 X_{3}$.

Figures 12 and 13 show the linear plots of observed versus predicted values of $\mathrm{BOD}_{5} / \mathrm{COD}$ ratio and percent COD removal, respectively.

The models adequacy checking is an important part of the data analysis procedure in which the approximating model would give poor or misleading results if it were an inadequate fit. The residual plots should always be examined for the approximating models. Actual values are the measured response data for particular run, and the predicted values evaluated from the model and generated by using the approximating functions. From the figures the correlation coefficients $R^{2}$ and $R_{\text {adj }}^{2}$ evaluated for $\mathrm{BOD}_{5} /$ COD ratio was found to be 0.86 and 0.82 , respectively, and for percent COD removal was 0.93 and 0.92 , respectively.

\subsubsection{Regression model-nonlinear}

In the regression model the dependent variables $\mathrm{BOD}_{5} /$ COD ratio $\left(\mathrm{Y}_{3}\right)$ and percent COD removal $\left(Y_{4}\right)$ of electrochemically oxidized effluent was regressed on duration of electrolysis $\left(X_{1}\right)$, voltage applied $\left(X_{2}\right)$, and current density $\left(X_{3}\right)$. The models are mathematically expressed in Eqs. 21 and 22 as follows:

$Y_{3}=A_{0} X_{1}^{A_{1}} X_{2}^{A_{2}} X_{3}^{A_{3}}$
$Y_{4}=B_{0} X_{1}^{B_{1}} X_{2}^{B_{2}} X_{3}^{B_{3}}$.

The correlation matrix gave the values of the regression coefficients of the nonlinear models. The estimated nonlinear model interrelating $\mathrm{BOD}_{5} / \mathrm{COD}$ ratio with the controlling parameters is given in Eq. 23, which has correlation coefficient $\left(R^{2}\right)$ of 0.90 . From the model, the most significant controlling parameter of the system affecting $\mathrm{BOD}_{5} / \mathrm{COD}$ ratio is the current density $\left(X_{3}\right)$ and the least significance parameter is the voltage $\left(X_{2}\right)$ applied.

$Y_{3}=-2.195 X_{1}^{0.008} X_{2}^{0.005} X_{3}^{2.25}$.

The estimated linear model interrelating percent COD removal with the controlling parameters is given in Eq. 24, which has correlation coefficient $\left(R^{2}\right)$ of 0.93 . From the model, the most significant controlling parameter of the system affecting percent COD removal is the current density $\left(X_{3}\right)$ and the least significant parameter is the electrolysis duration $\left(X_{1}\right)$.

$Y_{4}=15.066 X_{1}^{0.343} X_{2}^{1.749} X_{3}^{12.23}$.

Figures 14 and 15 show the nonlinear plots of observed versus predicted values of $\mathrm{BOD}_{5} / \mathrm{COD}$ ratio and percent COD removal, respectively. From the figures the correlation coefficients $R^{2}$ and $R_{\text {adj }}^{2}$ evaluated for $\mathrm{BOD}_{5} / \mathrm{COD}$ ratio was found to be 0.90 and 0.92 , respectively, and for percent COD removal was 0.93 and 0.97 , respectively. The results indicate that the nonlinear regression models gave the best results when compared with the linear models.

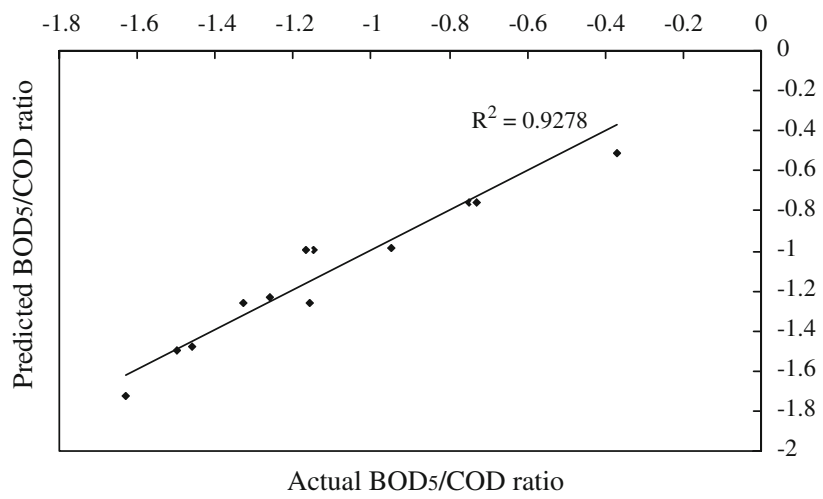

Fig. 14 Nonlinear regression plot of actual and predicted values of $\mathrm{BOD}_{5} / \mathrm{COD}$ 


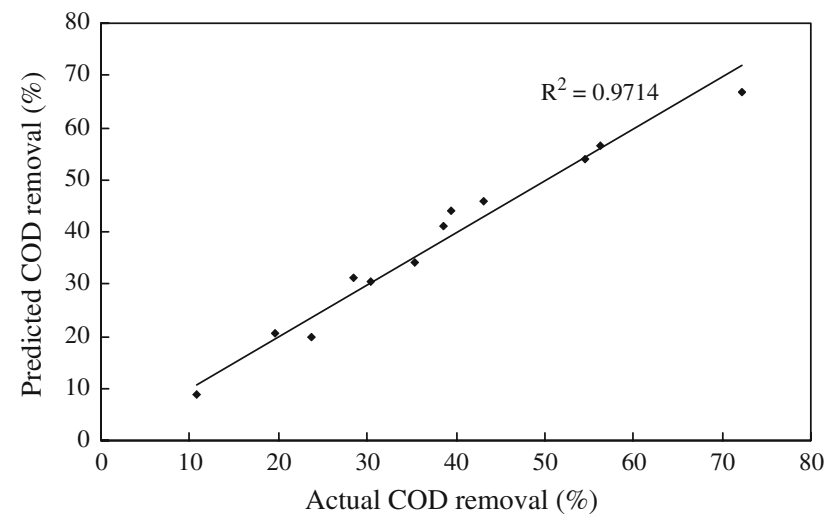

Fig. 15 Nonlinear regression plot of actual and predicted values of percent COD removal

\section{Conclusions}

Based on the findings of this study, the electrochemical technique can be effectively used for the pretreatment of distillery effluent using aluminum electrode. The electrolytic efficiency was primarily based on the efficiency of $\mathrm{COD}$ removal and improvement in $\mathrm{BOD}_{5} / \mathrm{COD}$ ratio. The efficiency of aluminum electrode in terms of COD removal was $72.3 \%$ at $120 \mathrm{~min}$ of electrolysis duration, at a current density of $0.03 \mathrm{~A} \mathrm{~cm}^{-2}$ and wastewater $\mathrm{pH}$ of 3 . There was an improvement in biodegradability of wastewater with $\mathrm{BOD} / \mathrm{COD}$ ratio increased from 0.16 to 0.68 . The maximum anodic efficacy of aluminum electrode for COD

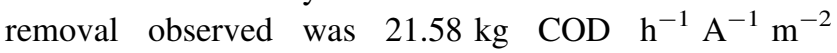
and the minimum energy consumption observed was $0.084 \mathrm{kWh} \mathrm{kg}^{-1}$ COD removed. The COD removal followed pseudo first-order kinetics and it was affected by the operating parameter mainly at $\mathrm{pH} 3$ and current density of $0.03 \mathrm{~A} \mathrm{~cm}^{-2}$. The linear and nonlinear regression models reveal that that percent COD removal and improvement in $\mathrm{BOD}_{5} / \mathrm{COD}$ ratio are more influenced by applied current density. Correlation coefficients $R^{2}$ and $R_{\text {adj }}^{2}$ of the observed and the predicted values of percent COD removal for linear model are 0.93 and 0.92 , respectively, and for nonlinear model are 0.93 and 0.97 , respectively. This reveals that the nonlinear regression model gives better correlation for percent COD removal. The ICE was found to be increase in ICE during first $30 \mathrm{~min}$ and sudden drop for further course of electrolysis. The decrease of ICE may be attributed to the growth of an adherent passivation film on the anode surface that might have poisoned the electrode or by production of stable intermediates that cannot be further oxidized by direct electrolysis. Although all organic contaminants of wastewater were significantly reduced during this study still COD and BOD were found to be high. It was found that the one step treatment by electrochemical process was not sufficient and further treatment by appropriate biological method is required to bring down the pollutant concentration within the statutory limits of effluent disposal.

Acknowledgments The authors would like to thank sincerely Dr. T.P. Halappa Gowda, Emeritus Professor, Department of Environmental Engineering, Sri Jayachamarajendra College of Engineering, Mysore, for his suggestions and to Dr. B.R. Niranjan, Professor and Chairman, Dr. H.N. Ramesh, Professor, Department of Civil Engg., UVCE, Bangalore University, Bangalore, and Dr. C. Nanjundaswamy, Professor and Head, Civil Engg. Department, Dr. AIT, Bangalore for their help and support while carrying out this research work. The authors are also thankful to Ms. B. Savitha, former M.Tech. Scholar for her help during the studies.

\section{References}

1. Kaul SN, Nandy T, Trivedy RK (1995) Pollution control in distilleries. Enviro Media, India

2. Salina B, Krishnakumar S, Saravanan A, Natarajan SK (2005) Res J Agric Biol Sci 1(2):166

3. Manisankar P, Viswanathan S, Rani C (2003) Green Chem 5:270

4. Pathade GR (2000) J Environ Prot 21(2):114

5. Dikshit AK, Chakraborty D (2006) Clean Technol Environ Policy 8(4):273

6. Garg VK, Guptha R (2002) Indian J Chem Technol 9:491

7. Panizza M, Michaud PA, Cerisola G, Comninellis C (2001) Electroanal Chem 507:206

8. Rao NN, Somashekhar KM, Kaul SN, Szpyrkowicz L (1997) J Chem Technol Biotechnol 76:1124

9. Wen TC (1990) Plat Surf Fin 77:54

10. Bejankiwar RS (2002) Water Res $36: 4386$

11. Bejankiwar RS, Lokesh KS, Gowda TPH (2003) J Environ Eng (ASCE) 129(11):1061

12. Chiang LC, Chang JE, Wen TC (1995) Water Res 29(2):671

13. Lin SH, Peng CF (1994) Water Res 28(2):277

14. Lin SH, Shyu CT, Sun MC (1998) Water Res 32(4):1059

15. Pletcher D, Walsh FC (1990) Industrial electrochemistry, 2nd edn. Chapman and Hall, London

16. Rajeshwar K, Ibanez JG, Swain GM (1994) J Appl Electrochem 24:1077

17. Bockris JOM, Bharadwaj RC, Tennakoon CLK (1994) Analyst 119:494

18. Savall A (1995) Chimia 49:23

19. Chiang LC, Chang JE, Tseng SC (1997) Water Sci Technol 36:123

20. Rajkumar D, Palanivelu K, Mohan N (2001) J Environ Sci Health A36:1997

21. Rajkumar D, Palanivelu K (2003) Ind Eng Chem Res 42:1833

22. Buos A, Balbo L, Giomo M, Farnia G, Sandona G (2000) Ind Eng Chem Res 39:494

23. Allen SJ, Khader KYH, Bino M (1995) J Chem Technol Biotechnol 62:111

24. Muthukumar K, Shunmuga Sundaram P, Anantharaman N, Basha C (2004) J Chem Technol Biotechnol 79:1135

25. Vijayaraghavan K, Ramanujam TK, Balasubramanian N (2001) Color Technol 117:49

26. Szpyrkowicz L, Juzzolino C, Kaul SN, Daniele S, De Faveri M (2000) Ind Eng Chem Res 39:3241

27. Panizza M, Bocca C, Cerisola G (2000) Water Res 34(9):2601

28. Szpyrkowicz L, Naumczyk J, Zilio-Grandi F (1995) Water Res 29:517

29. Vijayaraghavan K, Ramanujam TK, Balasubramanian N (1998) J Environ Eng 124:887 
30. George VK, Pandey S, Udupa N (1995) Res Ind 40:48

31. Deshpande A, Lokesh KS, Bejankiwar RS, Gowda TPH (2005) J Environ Sci Eng 47(1):21

32. Sharifian H, Kirk DW (1986) J Electrochem Soc 133:921

33. Comninellis C, Pulgarin C (1991) J Appl Electrochem 21:703

34. Comninellis C, Pulgarin C (1993) J Appl Electrochem 23:108

35. Tahar NB, Savall A (1998) J Electrochem Soc 145:3427

36. Bo W, Kong W, Ma H (2007) J Hazard Mater 146(1-2):295

37. Belaid C, Kallel M, Lalleve G, Elleuch B, Fauvarque J-F (2006) J Appl Electrochem 36:1175

38. Jegan J, Prabhakaran R, Basha CA (2002) J Environ Prot 22(1): 33

39. American Public Health Association (1998) Standard methods for examination of water and wastewater, 20th edn. APHA, AWWA, Washington, DC

40. Comninellis C (1994) Electrochem Acta 39(11/12): 1857

41. Manishankar P, Rani C, Vishwanathan S (2004) Chemosphere 57:961

42. Chen G (2004) Sep Purif Technol 38:11
43. Rajkumar D, Song BJ, Kim JG (2007) J Dyes Pigments 72:1

44. Feng JW et al (2007) J Environ Sci 19:1409

45. Holt PK, Barton GW, Wark M et al (2002) J Colloid surf A 211(2/3):233

46. Danesvar N, Oladegaragoze A, Djafarzadeh N (2006) J Hazard Mater 129(1-3): 116

47. Gurser A, Yalcin M, Dogan C (2002) Waste Manag 22:491

48. Rebhum M, Lurie M (1993) Water Sci Technol 27:1

49. Kobya M et al (2003) J Hazard Mater B100:163

50. Krishnaprasad R, Srivatsava SN (2009) Chem Eng J 146:22

51. Szpyrkowicz L et al (2001) Water Res 35(9):2129

52. Prentice G (1991) Electrochemical engineering principles. Prentice-Hall, Singapore

53. Piya-areetham P, Shenchunthichai K, Hunsom M (2006) Water Res 40:2857

54. Rajkumar D, Palanivelu K, Mohan N (2003) Indian J Chem Technol 10:396

55. Rajkumar D, Palanivelu K, Balasubramanian N (2005) J Environ Eng Sci 4:1 